\title{
BRD7 Gene
}

National Cancer Institute

\section{Source}

National Cancer Institute. BRD7 Gene. NCI Thesaurus. Code C157263.

This gene plays a role in SWI/SNF complex-dependent chromatin remodeling, Wnt signaling and p53-mediated cell cycle arrest. 